\title{
PENGARUH REWARD TERHADAP MOTIVASI KERJA KARYAWAN

\author{
(Studi pada Karyawan PT. Makitamega Makmur Perkasa)
}

\author{
Ivan Tomi Putra ${ }^{1}$, Ismail ${ }^{2}$, Lutfiaida Karimah ${ }^{3}$, Latifa Hannum Sihite ${ }^{4}$, Irma \\ Cahyani $^{5}$, Setia Mulyawan ${ }^{6}$ \\ 1,2,3,4,5,6 Universitas Islam Negeri Sunan Gunung Djati Bandung \\ Email : uinsgd.ac.id
}

\begin{abstract}
Abstrak
Penelitian ini bertujuan untuk menjelaskan pengaruh variabel reward, motivasi secara parsial terhadap kinerja karyawan. Penelitian ini menggunakan metode explanatory research dengan pendekatan kuantitatif dan sampel sebanyak 45 karyawan PT. Makitamega Makmur Perkasa. Instrumen penelitian yang digunakan adalah wawancara. Analisis data yang digunakan adalah analisis statistik deskriptif dan analisis jalur. Hasil analisis deskriptif menggambarkan bahwa reward, motivasi kerja karyawan dan kinerja karyawan sudah baik. Berdasarkan hasil analisis penelitian secara parsial reward, berpengaruh signifikan terhadap motivasi kerja karyawan dengan nilai koefisien beta reward sebesar 0,337 dan sig. 0,024. Sedangkan secara parsial motivasi kerja karyawan berpengaruh signifikan terhadap kinerja karyawan, hal ini ditunjukkan melalui koefisien beta reward sebesar 0,227 dan sig. 0,042. Koefisien motivasi kerja karyawan sebesar 0,561 dan nilai sig. 0,000 .
\end{abstract}

Kata kunci: Reward, Motivasi

\begin{abstract}
This research aims to examine the influence of reward and punishment partially on motivation, and explains the influence of reward, motivation partially to performance. This research is an explanatory research that use a quantitative approaching method and used 45 employees of Makitamega Makmur Perkasa Company. The research instruments used a interview The data analysis used statistic descriptive analysis and path analysis. The result of descriptive analysis shows that reward, motivation and performance are well perceived by the employees. The analysis reveals that partially reward gives significant effect to the motivation with beta coefficient of reward is 0,337, and the value of signification is 0,024. Partially motivation have effect significantly on the performance. It can be seen from the value of beta coefficient of reward is 0,227 and the value of signification is 0.042, and then the beta coefficient of punishment is 0,210 and the value of signification is 0,047. Beta coefficient of the work motivation is 0,561 and the value of signification is 0.000.
\end{abstract}

Keyword: Reward, Motivation

\section{A. PENDAHULUAN}


Perkembangan dunia bisnis yang semakin meningkat mendorong semakin tinggi pula tingkat persaingan dalam bidang usaha, tidak terkecuali dalam sektor jasa. Seiring dengan perkembangan tersebut, masalah yang dialami perusahaan semakin kompleks karena perusahaan akan menghadapi lebih banyak pesaing, namun perusahaan dituntut untuk dapat mencapai penjualan produk sesuai dengan target yang diharapkan melalui peningkatan kualitas pelayanan sumber daya manusia (SDM). Kualitas pelayanan

SDM yang maksimal terhadap konsumen sangat diperlukan dalam menjaga dan meningkatkan kualitas perusahaan. Mengingat pentingnya sumber daya manusia yang mencakup peran, pengelolaan, serta pendayagunaan karyawan diperlukan untuk memacu semangat kerja karyawan, perusahaan harus memenuhi beberapa kriteria melalui penerapan konsep dan teknik manajemen sumber daya manusia yang tepat, salah satunya melalui reward dan motivasi.

Reward dan motivasi sangat penting dalam memotivasi kinerja karyawan, karena melalui reward dan motivasi karyawan akan menjadi lebih berkualitas dan bertanggung jawab dengan tugas yang diberikan. Reward dan motivasi sangat erat hubungannya dengan pemberian motivasi karyawan tak terkecuali pada karyawan yang bergerak pada lembaga perbankkan dan non perbankan. Persaingan lembaga perbankkan maupun non perbankan semakin hari semakin ketat membuat persaingan semakin tajam sehingga setiap lembaga dituntut untuk memiliki strategi dalam meningkatkan kinerja karyawan salah satunya pada PT.Makitamega Makmur Perkasa.

PT. Makitamega Makmur Perkasa menerapkan sistem yang berorientasi pada target, sehingga setiap karyawan dituntut untuk aktif mencari nasabah sebanyak-banyaknya guna memenangkan pasar. Berdasarkan kondisi tersebut mendorong PT. Makitamega Makmur Perkasamelakukan pembenahan untuk memperbaiki segala kekurangan, baik dari sumber daya manusia, teknologi, dan pelayanannya. Keberhasilan dalam melaksanakan tugas pokok dan fungsi di PT. Makitamega Makmur Perkasa akan sangat tergantung dari kinerja para karyawannya. Dengan kinerja karyawan yang semakin baik dan meningkat,dan semakin baik. Persaingan dalam bisnis perbankan semakin ketat, membuat perusahaan dituntut untuk dapat membangun suatu kebijakan untuk mengembangkan dan mempertahankan kinerja karyawan supaya tetap optimal salah satunya melalui reward dan Motivasi Tujuan penerapan reward dan motivasi tersebut adalah untuk mendorong karyawan bergerak aktif. 


\section{B. KAJIAN PUSTAKA}

Reward

Menurut Nawawi (2005:319), “reward adalah usaha menumbuhkan perasaan diterima (diakui) di lingkungan kerja, yang menyentuh aspek kompensasi dan aspek hubungan antara para pekerja yang satu dengan yang lainnya”. Manajer mengevaluasi hasil kinerja individu baik secara formal maupun informal menurut Matteson dalam Koencoro (2013:2) reward dibagi menjadi dua jenis yaitu reward extrinsik dan reward intrinsik. Penghargaan ekstrinsik (ekstrinsic rewards) adalah suatu penghargaan yang datang dari luar diri orang tersebut. Penghargaan ekstrinsik terdiri dari penghargaan finansial yaitu Gaji, Tunjangan, Bonus/insentif dan penghargaan non finansial yaitu penghargaan interpersonal serta promosi. Penghargaan intrinsik (intrinsic rewards) adalah suatu penghargaan yang diatur oleh diri sendiri yang terdiri dari Penyelesaian (completion), Pencapaian (achievement), dan Otonomi.

\section{Motivasi Kerja}

Motivasi menurut Purwanto dalam Pahlevi (2012:45) adalah "usaha yang disadari untuk mempengaruhi tingkah laku seseorang agar tergerak hatinya untuk bertindak melakukan sesuatu yang mencapai hasil atau tujuan tertentu". Motivasi kerja menurut Hasibuan (2003:97) memiliki beberapa tujuan diantaranya mendorong gairah dan semangat kerja karyawan, meningkatkan moral dan kepuasan kerja karyawan, meningkatkan produktivitas kerja karyawan, mempertahankan loyalitas dan kestabilan karyawan perusahaan, meningkatkan kedisiplinan dan menurunkan tingkat absensi karyawan, mengefektifkan pengadaan karyawan, menciptakan suasana dan hubungan kerja yang baik, meningkatkan kreativitas dan partisipasi karyawan, meningkatkan tingkat kesejahteraan karyawan, mempertinggi rasa tanggung jawab karyawan terhadap tugas-tugasnya dan Meningkatkan efisiensi penggunaan alat-alat dan bahan baku.

\section{Kinerja Karyawan}

Kinerja (prestasi kerja) menurut Mangkunegara (2009 : 67) adalah "hasil kerja secara kualitas dan kuantitas yang dicapai oleh seorang pegawai dalam melaksanakan tugasnya sesuai dengan tanggung jawab yang diberikan kepadanya". dapat disimpulkan bahwa kinerja karyawan merupakan hasil kerja yang telah dicapai seorang karyawan atas tanggung jawab yang telah diberikan baik secara kualitas maupun kuantitas guna 
mencapai tujuan strategis organisasi, kepuasan konsumen serta memberikan kontribusi pada kemajuan ekonomi.

Menurut Dharma dalam Koencoro (2013:4) ada tiga cara pengukuran yang dapat digunakan antara lain:

1. Kuantitas, yang berkaitan dengan jumlah yang harus diselesaikan. Merupakan ukuran kuantitatif yang melibatkan perhitungan dari proses atau pelaksanaan kegiatan. Hal ini berkaitan dengan soal jumlah keluaran yang dihasilkan, sehingga untuk mengetahui tinggi rendahnya prestasi kerja karyawan tersebut dibandingkan dengan standar kuantitas yang ditetapkan oleh perusahaan.

2. Kualitas, yang berkaitan dengan mutu yang dihasilkan (baik buruknya) ukuran kuantitatif yang mencerminkan "tingkat kepuasan” yaitu seberapa baik penyelesaian dari suatu perusahaan walaupun standar kualitatif sulit diukur atau ditentukan, tetapi hal ini penting sebagai acuan pencapaian sasaran penyelesaan suatu pekerjaan.

3. Ketepatan Waktu, yaitu berkaitan dengan sesuai tidaknya dengan waktu yang telah direncanakan. Merupakan suatu jenis khusus, dari ukuran kuantitatif yang merupakan ketepatan waktu penyelesaian suatu kegiatan. Dalam hal ini penetapan standar waktu biasa ditentukan berdasarkan pengalaman sebelumnya atau berdasarkan studi gerak waktu. dengan pemberian hadiah atas hasil pekerjaannya, karyawan akan lebih bekerja maksimal. Sedangkan punishment dimunculkan bagi seorang karyawan yang melakukan kesalahan dan pelanggaran agar termotivasi untuk menghentikan perilaku menyimpang dan mengarahkan pada perilaku positif. Berdasarkan pernyataan diatas dapat disimpulkan bahwa reward dan punishment digunakan untuk memotivasi karyawan supaya kinerja dapat berjalan secara maksimal. Oleh sebab itu diharapkan pemimpin dapat berusaha untuk mengelola sistem reward dan punishment dengan baik.

\section{Pengaruh Reward dan Motivasi terhadap Kerja Karyawan}

Sukses atau tidaknya perusahaan dapat dilihat melalui kinerja para karyawannya. Apabila kinerja para karyawan baik maka akan berdampak pada profit perusahaan. Untuk mencapai kinerja yang optimal dibutuhkan suatu motivasi dalam diri karyawan. Sifat manusia dalam sebuah organisasi diasumsikan dengan asumsi teori $\mathrm{X}$ dan teori $\mathrm{Y}$ seperti yang dikemukakan oleh Gregor. MC (1988) dalam (Hasibuan, 2003:123). Asumsi teori X berisi tentang sifat-sifat negatif individu misalnya tidak suka bekerja, tidak ambisius, 
tidak kreatif dan malas, sedangkan asumsi teori $\mathrm{Y}$ berisi tentang sifat-sifat positif individu misalnya semangat bekerja, memiliki ambisi kearah lebih baik, kreatif dan rajin. Usaha meminimalkan asumsi teori $\mathrm{X}$ tersebut dengan melakukan arahan, paksaan, punishment dan membuat aturan agar tujuan perusahaan dapat tercapai.

Pada dasarnya, baik reward maupun punishment sama-sama dibutuhkan untuk merangsang karyawan agar meningkatkan kualitas kerjanya. Kedua sistem tersebut digunakan sebagai bentuk reaksi pimpinan terhadap kinerja yang ditunjukkan oleh karyawannya. Meskipun sekilas fungsi keduanya berlawanan namun pada dasarnya samasama bertujuan agar seseorang menjadi lebih baik, lebih berkualitas dan bertanggung jawab dengan tugas yang diberikan.

Reward dimunculkan untuk memotivasi seseorang supaya giat dalam menjalankan tanggung jawab karena terdapat anggapan bahwa dengan pemberian hadiah atas hasil pekerjaannya, karyawan akan lebih bekerja maksimal. Sedangkan punishment dimunculkan bagi seorang karyawan yang melakukan kesalahan dan pelanggaran agar termotivasi untuk menghentikan perilaku menyimpang dan mengarahkan pada perilaku positif. Berdasarkan pernyataan diatas dapat disimpulkan bahwa reward dan punishment digunakan untuk memotivasi karyawan supaya kinerja dapat berjalan secara maksimal. Oleh sebab itu diharapkan pemimpin dapat berusaha untuk mengelola sistem reward dan punishment dengan baik.

\section{METODE PENELITIAN}

Jenis penelitian yang digunakan dalam penelitian ini adalah penelitian penjelasan (explanatory research) dengan pendekatan kuantitatif. Lokasi dalam penelitian ini adalah pada PT. Makitamega Makmur Perkasa yang berada di Harco Mangga Dua Ruko Pesona Bahari, Jl. Mangga Dua Abdad Blok. R No.2 - Jakarta Pusat. Variabel yang diteliti adalah Reward, Motivasi Kerja Karyawan. Populasi dalam penelitian ini adalah seluruh karyawan yang ada pada PT. Makitamega Makmur Perkasa sebanyak 45 karyawan. Sampel yang digunakan pada penelitian ini sejumlah 45 karyawan dengan menggunakan teknik pengambilan sampel yaitu dengan teknik wawancara.

\section{Uji Validitas dan Reliabilitas}

Menurut Arikunto (2010:16), "validitas adalah suatu ukuran yang menunjukkan tingkat- tingkat ketepatan atau kesahihan suatu instrumen. Pengujian validitas dalam 
penelitian ini adalah dengan menghitung korelasi diantara masing- masing pernyataan dengan skor total menggunakan korelasi product moment. Syarat minimum untuk dianggap valid adalah nilai rhitung $>$ dari nilai rtabel atau jika koefisien korelasinya $\square 0,3$. Hasil uji validitas menunjukkan bahwa seluruh item mempunyai nilai $\mathrm{r}$ (koefisien korelasi) lebih besar dari 0,3 , sehingga instrumen pada penelitian ini dikatakan valid.

Pengujian reliabilitas digunakan untuk mengetahui apakah pernyataan dalam kuesioner reliabel, artinya menunjukkan sejauh mana item pernyataan yang digunakan dapat dipercaya dan dapat diandalkan untuk digunakan sebagai alat ukur dalam penelitian. Pengukuran reliabilitas dilakukan dengan cara menghitung koefisien Alpha Cronbach $(\alpha)$. Variabel dikatakan reliabel jika Alpha cronbach memiliki nilai lebih besar dari 0,6. Hasil uji reliabilitas menunjukkan bahwa seluruh variabel mempunyai koefisien alpha lebih besar dari 0,6 sehingga instrumen pada penelitian ini dikatakan reliabel.

\section{Analisis Data}

Data yang telah diperoleh dianalisis dengan menggunakan analisis statistik deskriptif dan analisis jalur (path analysis). Analisis statistik deskriptif digunakan untuk mengetahui gambaran responden yang menjadi subjek penelitian melalui frekuensi dan variasi jawaban reponden terhadap item/ butir pernyataan. Analisis jalur digunakan untuk menjelaskan besarnya pengaruh langsung dan tidak langsung antar variabel dalam penelitian ini.

\section{HASIL PENELITIAN DAN PEMBAHASAN}

\section{Gambaran Responden}

Hasil analisis deskriptif menggambarkan bahwa dari 45 orang responden pada penelitian ini, 40,0\% pria dan $5 \%$. wanita. Rata-rata masa kerja karyawan berkisar 1-5 tahun dengan rata-rata usia 22-29 tahun sedangkan pendidikan terakhir mayoritas karyawan adalah SMA Jurusan IPA dan perguruan tinggi.

\section{Analisis Statistik Deskriptif}

Berdasarkan distribusi frekuensi variable reward (X1) nilai mean mendapatkan skor sebesar 3,73 terletak pada interval kelas $>3,4-4,2$ yang artinya rata-rata karyawan menyakini bahwa reward yang berlaku pada PT. Makitamega Makmur Perkasa sudah dilakukan dengan baik. Distribusi frekuensi variabel Motivasi (Y1) mendapatkan mean sebesar 4,18 terletak pada interval kelas >3,4-4,2 yang artinya rata-rata karyawan menyakini 
bahwa Motivasi yang berlaku pada PT. Makitamega Makmur Perkasa sudah dilakukan dengan baik. Distribusi Frekuensi variabel Kinerja (Y2) mendapatkan mean sebesar 3,98 terletak pada interval kelas >3,4 - 4,2 yang artinya rata-rata karyawan menyakini bahwa Kinerja yang berlaku pada PT. Makitamega Makmur Perkasa sudah dilakukan dengan baik.

\section{Analisis Jalur (Path Analysis)}

Tabel 1 Menunjukkan hasil analisis jalur antara variabel Reward, Motivasi Kerja Karyawan Tabel 1. Hasil Uji Analisis Jalur (Path Analysis)

\begin{tabular}{|c|c|c|c|c|c|c|}
\hline 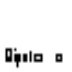 & 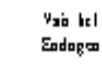 & 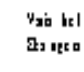 & it & $\mathrm{fi}$. & $\underset{\mathbf{m}}{\text { Kanog }}$ & $\begin{array}{c}R_{213 x} \\
||^{2} \mid\end{array}$ \\
\hline 0 & firworrd & 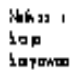 & 0,337 & 0,024 & 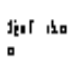 & 0,163 \\
\hline 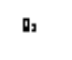 & fimorre & 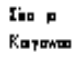 & $0,2 n$ & 0,042 & 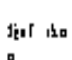 & 1,54 \\
\hline
\end{tabular}

\section{H1: Reward berpengaruh signifikan terhadap Motivasi Kerja Karyawan}

Tabel 1 menunjukkan hasil pengujian analisis jalur untuk mengetahui signifikansi pengaruh reward terhadap motivasi kerja karyawan. Tabel 1 menunjukkan angka $\mathrm{R}$ square (R2) sebesar 0,163. Koefisien jalur $(\beta)$ pada pengaruh reward terhadap motivasi kerja karyawan adalah 0,337 dengan sig. 0,024 (sig <0,05) maka keputusan H1 diterima, artinya reward berpengaruh signifikan terhadap motivasi kerja Karyawan.

\section{H2: Motivasi berpengaruh signifikan terhadap Motivasi Kerja Karyawan}

Tabel 1 menunjukkan hasil pengujian analisis jalur untuk mengetahui signifikansi pengaruh motivasi terhadap motivasi kerja karyawan. Tabel 1 menunjukkan angka $R$ square (R2) sebesar 0,163 dan koefisien jalur $(\beta)$ pada pengaruh motivasi terhadap motivasi kerja karyawan adalah 0,147 dengan sig. 0,313 (sig > 0,05) maka keputusan $\mathrm{H} 2$ ditolak, artinya motivasi berpengaruh tidak signifikan terhadap motivasi kerja karyawan.

\section{H3: Reward berpengaruh signifikan terhadap Kinerja Karyawan}

Tabel 1 menunjukkan hasil pengujian analisis jalur untuk mengetahui pengaruh reward terhadap kinerja karyawan. Tabel 1 menunjukkan angka $\mathrm{R}$ square (R2) sebesar 0,59 dan koefisien jalur $(\beta)$ pada hubungan reward terhadap kinerja karyawan adalah 0,210 dengan sig. 0,047 (sig < 0,05) maka keputusan H4 diterima, artinya reward berpengaruh signifikan terhadap kinerja karyawan. 
H5: Motivasi Kerja Karyawan berpengaruh signifikan terhadap Kinerja Karyawan

Tabel 1 menunjukkan hasil pengujian analisis jalur untuk mengetahui pengaruh motivasi kerja karyawan terhadap kinerja karyawan. Tabel 1 menunjukkan angka $\mathrm{R}$ square (R2) sebesar 0,59 dan koefisien jalur ( $\beta$ ) pada pengaruh motivasi kerja karyawan terhadap kinerja karyawan adalah 0,561 dengan sig. sebesar 0,000 (sig < 0,05) maka keputusan H5 diterima, artinya motivasi kerja karyawan berpengaruh signifikan terhadap kinerja karyawan.

\section{Pembahasan Hasil Penelitian}

\section{Pengaruh Reward terhadap Motivasi Kerja Karyawan}

Dari hasil penelitian diatas dapat ditarik kesimpulan bahwa reward memberikan pengaruh signifikan terhadap motivasi kerja karyawan hal itu sesuai pendapat yang dikemukakan Gitosudarmo (2000:226) yaitu salah satu dasar tujuan reward adalah memotivasi anggota organisasi. Maksud dari pernyataan tersebut adalah sistem imbalan atau reward dirancang oleh perusahaan bertujuan untuk memacu gairah kerja para karyawannya supaya dapat meningkatkan prestasinya dalam bekerja. Berdasarkan hasil diatas dapat dikatakan bahwa motivasi kerja karyawan akan terbentuk dengan adanya reward baik yang berasal dari gaji, tunjangan, bonus, Penghargaan interpersonal,

Pencapaian (Achievement), maupun dari otonomi, sehingga dapat disimpulkan bahwa terdapat pengaruh signifikan antara kedua variabel, yang artinya pemberian reward pada PT. Makitamega Makmur Perkasa telah sesuai dengan harapan karyawan sehingga dapat meningkatkan motivasi kerja karyawan. Penelitian ini serupa dengan penelitian yang telah dilakukan oleh Purwantono (2014) bahwa terdapat pengaruh positif reward terhadap motivasi kerja, sehingga penelitian ini mendukung hasil dari penelitian yang dilakukan oleh Purwantono (2014) dimana reward berpengaruh dan signifikan terhadap motivasi karyawan

\section{Pengaruh Reward terhadap Kinerja Karyawan}

Dari penelitia diatas dapat ditarik kesimpulan bahwa reward memberikan pengaruh yang signifikan terhadap kinerja karyawan dan hal tersebut sesuai dengan pendapat yang dikemukakan oleh Oemar (2007:127) bahwa reward merupakan imbalan yang diberikan perusahaan kepada karyawan atas kinerja yang telah diberikan. Maksudnya 
adalah reward diberikan perusahaan kepada karyawan sebagai bentuk apresiasi perusahaan kepada karyawan atas dedikasi atau kinerja yang telah diberikan. Secara umum pemberian reward pada karyawan bertujuan untuk meningkatkan kinerja karyawan sehingga tujuan perusahaan dapat tercapai, selain itu dengan adanya reward karyawan merasa kontribusi yang diberikan dihargai sehingga memacu kinerja karyawan menjadi semakin meningkat. Dapat dikatakan bahwa kinerja karyawan dipengaruhi oleh adanya reward baik yang berasal dari gaji, tunjangan, bonus, Penghargaan interpersonal berupa pujian, promosi, Pencapaian (Achievement) berupa rasa puas dan bangga, maupun dari otonomi. Berdasarkan hasil penelitian terdapat pengaruh signifikan antara kedua variabel, yang artinya pemberian reward pada PT. Makitamega Makmur Perkasa telah sesuai dengan harapan karyawan sehingga dapat meningkatkan kinerja karyawan. Penelitian tersebut mendapatkan hasil yang serupa dengan penelitian yang telah dilakukan oleh Mansyur (2013) yang menyatakan bahwa Reward berpengaruh signifikan terhadap kinerja pegawai, sehingga penelitian ini dapat mendukung penelitian yang dilakukan oleh Mansyur dimana reward berpengaruh signifikan terhadap Kinerja Karyawan.

\section{Pengaruh Motivasi Kerja Karyawan terhadap Kinerja Karyawan}

Dari penelitian diatas dapat disimpulkan bahwa motivasi kerja karyawan memberikan pengaruh yang signifikan terhadap kinerja karyawan hal tersebut diperkuat dengan pendapat yang dikemukakan oleh Davis (1964:484) dalam Mangkunegara (2009: 67) merumuskan salah satunya bahwa kinerja terdiri dari kemampuan dan motivasi. Maksud dari pernyataan diatas adalah untuk membentuk kinerja yang baik dibutuhkan kemampuan dan motivasi pada karyawan, karena apabila pada suatu perusahaan telah memiliki karyawan atau sumber daya manusia dengan kemampuan yang berkualitas secara otomatis kinerja karyawan berdampak pada perusahaan yaitu dapat menembus target yang telah ditentukan sehingga tidak merugikan perusahaan. Namun jika hanya kemampuan tanpa diimbangi motivasi maka hal tersebut tidak akan berarti karena motivasi bagi individu sangatlah penting sebagai pendorong girah kerja seseorang. Berdasarkan hasil penelitian dapat diketahui bahwa motivasi karyawan berpengaruh signifikan pada kinerja karyawan yang artinya motivasi kerja karyawan pada PT. Panin Bank Tbk. Area Mikro Jombang telah sesuai dengan harapan karyawan sehingga dapat meningkatkan kinerja karyawan. Penelitian tersebut serupa dengan penelitian yang telah dilakukan oleh Tinggogoy, dkk (2013) bahwa Motivasi Kerja akan meningkatkan kinerja karyawan, sehingga penelitian ini 
mendukung penelitian yang dilakukan oleh Tinggogoy, dkk bahwa motivasi berpengaruh signifikan terhadap kinerja karyawan.

\section{E. KESIMPULAN}

Secara keseluruhan distribusi frekuensi pada variabel X1 (reward), variabel Y1 (motivasi kerja karyawan), pada PT. Panin Bank Tbk Area Miro Jombang telah berjalan dengan baik. Hasil pengumpulan data sekunder bahwa reward pada PT. Makitamega Makmur berupa gaji setiap bulannya, tunjangan berbentuk tunjangan hari raya dan tunjangan kesehatan, Bonus berbentuk wisata yang dilakukan karyawan atas kesepakatan bersama, Penghargaan interpersonal berupa pujian yang dilakukan pemimpin. Promosi pada PT. Makitamega Makmur dilaksanakan berdasarkan kinerja dan masa kerja. Achievement atau pencapaian berupa rasa puas dan bangga dan yang terakhir mengenai otonomi yaitu karyawan memiliki hak yang sama dalam mengambil keputusan sesuai dengan peraturan perusahaan. Penilaian kinerja karyawan pada PT. Makitamega Makmur terdiri dari 2 bagian utama yaitu melalui hasil kerja dan prestasi dengan tingkat penilaian sebesar $70 \%$ serta melalui implementasi tata nilai I CARE sebesar 30\%. Reward berpengaruh signifikan terhadap motivasi kerja karyawan. Reward berpengaruh signifikan terhadap kinerja karyawan. Motivasi berpengaruh signifikan terhadap kinerja karyawan.

Berdasarkan kesimpulan yang diperoleh dalam penelitian ini, maka dapat dikemukakan beberapa saran bagi pihak -pihak yang berkepentingan sebagai berikut:

1. Hendaknya pihak PT. Makitamega Makmur dapat mempertahankan dan lebih memperbaiki. Hal tersebut dimaksudkan agar motivasi yang ada pada diri karyawan akan dapat dipertahankan dan semakin meningkat.

2. Reward yang telah berlaku pada PT. Makitamega Makmur telah diterapkan dengan baik. Namun guna lebih meningkatkan kinerja karyawan sebaiknya perusahaan memberikan beberapa alternatif reward yang diberikan kepada karyawan karena dengan bertambahnya alternatif reward yang dapat diperoleh maka secara otomatis karyawan akan meningkatkan kinerjanya dalam beberapa aspek pekerjaan.

3. Pada peneliti selanjutnya, hendaknya mampu memberikan tambahan-tambahan teori yang mendukung sehingga akan dapat memberikan gambaran baru khususnya mengenai reward dan punishment. Serta diharapkan penelitian ini dapat dijadikan 
bahan acuan dan perbandingan dalam melakukan penelitian serupa dimasa yang akan datang.

\section{DAFTAR PUSTAKA}

Arikunto, Suharsimi. 2010. Prosedur Penelitian. Suatu Pendekatan Praktek. Edisi Revisi V. Jakarta: Rineka Cipta.

Hasibuan, Malayu. S.P. 2003. Organisasi dan Motivasi Dasar Peningkatan Produktivitas. Jakarta : PT. Bumi Aksara.

Mangkunegara, AP. 2000. Manajemen Sumber Daya Manusia, Cetakan Pertama. Bandung : Rosada.

Mangkunegara, AP. 2009. Manajemen Sumber Daya Manusia Perusahaan. Bandung: PT. Remaja Rosdakarya.

Pahlevi, Resa Nur. 2012. Pengaruh Penerapan Reward dan Punishment Terhadap Kinerja Pegawai Negeri Sipil di Badan Kepegawaian dan Diklat Kota Cilegon. Skripsi Sarjana pada Universitas Sultan Ageng Tirtayasa, Serang (online). 